\title{
STEPPING STONES: \\ PRINCIPAL CAREER PATHS AND SCHOOL OUTCOMES
}

\author{
Tara Béteille \\ Demetra Kalogrides \\ Susanna Loeb \\ Working Paper 17243 \\ http://www.nber.org/papers/w17243
}

\author{
NATIONAL BUREAU OF ECONOMIC RESEARCH \\ 1050 Massachusetts Avenue \\ Cambridge, MA 02138 \\ July 2011
}

This research was supported by grants from the Hewlett Foundation and the Spencer Foundation. The views expressed herein are those of the authors and do not necessarily reflect the views of the National Bureau of Economic Research.

NBER working papers are circulated for discussion and comment purposes. They have not been peerreviewed or been subject to the review by the NBER Board of Directors that accompanies official NBER publications.

(C) 2011 by Tara Béteille, Demetra Kalogrides, and Susanna Loeb. All rights reserved. Short sections of text, not to exceed two paragraphs, may be quoted without explicit permission provided that full credit, including $\odot$ notice, is given to the source. 
Stepping Stones: Principal Career Paths and School Outcomes

Tara Béteille, Demetra Kalogrides, and Susanna Loeb

NBER Working Paper No. 17243

July 2011

JEL No. I21

\begin{abstract}
$\underline{\text { ABSTRACT }}$
More than one out of every five principals leaves their school each year. In some cases, these career changes are driven by the choices of district leadership. In other cases, principals initiate the move, often demonstrating preferences to work in schools with higher achieving students from more advantaged socioeconomic backgrounds. Principals often use schools with many poor or low-achieving students as stepping stones to what they view as more desirable assignments. We use longitudinal data from one large urban school district to study the relationship between principal turnover and school outcomes. We find that principal turnover is, on average, detrimental to school performance. Frequent turnover of school leadership results in lower teacher retention and lower student achievement gains. Leadership changes are particularly harmful for high poverty schools, low-achieving schools, and schools with many inexperienced teachers. These schools not only suffer from high rates of principal turnover but are also unable to attract experienced successors. The negative effect of leadership changes can be mitigated when vacancies are filled by individuals with prior experience leading other schools. However, the majority of new principals in high poverty and low-performing schools lack prior leadership experience and leave when more attractive positions become available in other schools.
\end{abstract}

Tara Béteille

The World Bank

MSN M9A-007

1900 Pennsylvania Avenue, NW

Washington, DC 20431

tara.beteille@gmail.com

Demetra Kalogrides

Stanford University

520 Galvez Mall Drive

Stanford CA, 94305

dkalo@stanford.edu
Susanna Loeb

524 CERAS, 520 Galvez Mall

Stanford University

Stanford, CA 94305

and NBER

sloeb@stanford.edu 


\section{INTRODUCTION}

In 2009 the Obama administration allocated four billion dollars to transform some of the nation's worst schools. Persistently low-achieving schools are eligible to receive federal grants to support intervention efforts but must make radical changes to their school in order to receive funds, including replacing their principals and in some cases large portions of their teaching staffs (Dillon 2011; Tucker 2010; U.S. Department of Education 2010). ${ }^{1}$ Though prior research provides evidence that principals have important effects on school outcomes and, thus, suggests that leadership change can be beneficial (Hallinger and Heck 1998; Hallinger and Heck 1996; Leithwood, Louis, Anderson, and Wahlstrom 2004), frequently replacing principals may create instability in schools that can potentially undermine improvement efforts (Dillon 2011).

Leadership changes in the lowest achieving schools sometimes result from involuntary termination, however, voluntary principal exits are also quite common (Gates, Ringel, Santibanez, Guarino, Ghosh-Dastidar, and Brown 2005; Loeb, Kalogrides, and Horng 2010; Papa, Lankford, and Wyckoff 2002a). Many schools-particularly schools with disadvantaged student populations_-face high rates of principal turnover driven, in part, by principals' desires to move to schools that they find more appealing (Loeb, Kalogrides, and Horng 2010).

It is unclear a priori whether leadership changes are beneficial or detrimental to schools. Studies of leadership turnover in other types of organizations suggest that turnover can have either beneficial or detrimental effects on organizations depending on the circumstances (Abelson and Baysinger 1984; Mobley 1982). Turnover can have beneficial effects if it helps generate new ideas and innovation and purges an organization of ineffective leaders (Brown 1982; Denis and Denis 1995). If ineffective principals are the most likely to leave, then

\footnotetext{
${ }^{1}$ See the following websites for more information: http://www2.ed.gov/programs/sif/nastid2.pdf and http://www2.ed.gov/programs/sif/sigguidance11012010.pdf
} 
leadership turnover may be beneficial to schools. At the same time, too much turnover can have negative consequences if it leads to instability, loss of institutional memory, high training costs or lower employee commitment (Abelson and Baysinger 1984; Grusky 1960; Mobley 1982).

The effects of leadership changes on school performance have not been rigorously examined in prior research. Such analyses are complicated because in order to identify the effects of principal turnover, researchers need to separate the effects of principal turnover from the effects of factors that cause principals to leave their position that may also be associated with school performance. In this paper we used detailed administrative data from one urban district to describe principal turnover and examine its effects on teacher retention and student achievement. We use changes over time within schools to identify these effects, carefully assessing the time trends in teacher retention and student achievement pre and post principal turnover.

In describing principal turnover, we find that when principals leave a school it is usually due to a transfer to another school in the district rather than attrition from the principal profession via termination. Unlike studies of turnover in other organizations which tend to find that poor performance is a precursor to managerial exits, we find that school performance bears little association with principal turnover. Principals who transfer tend to move to schools with more advantaged and higher achieving student bodies relative to where they start, suggesting that principals may use their initial school assignments as stepping stones to more desirable future positions in other schools. The patterns of principal movement we observe are consistent with principals' stated preferences for more advantaged and higher achieving schools.

In estimating the effects of principal turnover, we find that this mobility in principals' career paths has detrimental consequences for schools. The departure of a principal is associated with higher teacher turnover rates and lower student achievement gains. The negative effects of 
principal turnover on student achievement are largest in schools with high concentrations of novice teachers, high concentrations of poor students and in schools with the lowest performance in the state's accountability system. The latter group of schools is precisely the type that is the target of the recent federal reforms previously discussed. Poorly performing schools and those with high concentrations of poor students not only experience much higher principal turnover rates than other schools, but they are also unable to attract experienced new principals when vacancies arise.

\section{BACKGROUND}

Many districts face very high rates of leadership turnover. Annual principal turnover rates in school districts throughout the country range from 15 to 30 percent each year with especially high rates of turnover in schools serving more low-income, minority and low-achieving students (Branch, Hanushek, and Rivkin 2008; DeAngelis and White 2011; Fuller and Young 2009; Gates et al. 2005; Loeb, Kalogrides, and Horng 2010; Ringel, Gates, Chung, Brown, and GhoshDastidar 2004). A principal may leave his or her current school either because of involuntary departure due to firing or reassignment or voluntary departure based on a preference to work in a different school. The former is the type of turnover generated by reform efforts intended to turn around failing schools by removing the leadership. Dismissal generally accounts for only a small proportion of all principal exits. Though there are no national figures on the frequency of principal firings, data from several school districts suggest that the majority of principal turnover (as experienced by individual schools) comes from intra-district transfers and not from exits (Gates et al. 2005; Loeb, Kalogrides, and Horng 2010; Ringel et al. 2004). District leadership may also reassign principals because they believe that bringing new leadership into schools on a regular basis is beneficial for school improvement (though we are aware of no empirical 
evidence that supports this belief). However, there is evidence that principals' movement across schools is, at least in part, voluntary (Loeb, Kalogrides, and Horng 2010).

When principals transfer, they generally move to a school with more affluent and higher achieving students relative to where they start (Loeb, Kalogrides, and Horng 2010; Papa, Lankford, and Wyckoff 2002a). Principals usually do not receive pay increases when they change schools within a district; therefore; intra-district transfers can improve only nonpecuniary benefits. Prior research suggests that many non-salary job characteristics affect teacher and principal preferences including student characteristics, school culture, facilities, and safety (Horng 2009; Loeb, Kalogrides, and Horng 2010; Loeb and Reininger 2004). These working conditions vary considerably across schools. Schools with less appealing attributes generally receive fewer applicants for vacant principal positions than do other schools, and therefore cannot be as selective when hiring replacements (Roza 2003). Consequently, new principals in such schools tend to have less experience leading other schools and are less likely to have advanced degrees than principals in other schools (Loeb, Kalogrides, and Horng 2010).

\subsection{Effects of Leadership Turnover}

Whether leadership changes are beneficial or detrimental for schools is unclear. No other study that we are aware of has examined the effects of principal turnover on school performance. Studies on the effects of leadership turnover in other types of organizations start with conflicting hypotheses and provide conflicting evidence. Some find that leadership turnover improves organizational performance (Brown 1982; Denis and Denis 1995; Grusky 1963; Virany, Tushman, and Romanelli 1992). This improvement happens when a manager in a struggling organization is replaced by a more effective manager. Other studies postulate or find that leadership turnover can be harmful for organizational performance (Audas, Dobson, and 
Goddard 2002; Azoulay, Zivin, and Wang 2010; Grusky 1963). In particular, frequent turnover may create instability in an organization. While poor performance may precede managerial change, when changes are frequent, they can be disruptive and make matters worse rather than better. Faltering organizations with high levels of turnover often have difficulty attracting experienced successors, who tend to be more effective (Pfeffer and Davis-Blake 1986). As a result, they become trapped in a "vicious circle" of high managerial turnover and declining performance (Grusky 1963). The "vicious circle" concept suggests that poorly performing organizations are especially vulnerable to the negative effects of leadership turnover. A final relevant group of studies hypothesize that leadership change plays no role in organizational performance (Brown 1982; Eitzen and Yetman 1972; Gamson and Scotch 1964; Smith, Carson, and Alexander 1984). This hypothesis, originally posited by Gamson and Scotch (1964), maintains that success results from organizational processes that are largely outside the control of middle management. Dismissing a manager is a gesture aimed at appeasing stakeholders or of deflecting attention from shortcomings at higher levels of management. Therefore, any relationship between management succession and performance is spurious. Gamson and Scotch (1964) refer to this idea as the "ritual scapegoating" theory. From this perspective, managers are either relatively unimportant or they are all of similar quality such that it makes little difference who fills the leadership role.

These hypotheses were developed in studies of involuntary leadership turnover when managers in struggling organizations are replaced. The effects of leadership turnover in schools may differ. Given the dynamics of the principal labor market described above and the voluntary nature of most principal turnover, leadership change in schools may not provide the beneficial mechanism of replacing less effective leaders with more effective leaders as often as it does in 
the private sector. Moreover, research on school reform suggests that organizational stability is an important component of a well running school and that frequent changes to staff undermine efforts to effectively implement a school's instructional program (Fuller and Young 2009; Hallinger and Heck 1996; Weinstein, Jacobowitz, Ely, Landon, and Schwartz 2009). Because of its disruptive effects, leadership turnover may be particularly likely to negatively impact school performance (Brown 1982), particularly in faltering schools with lower resource levels, more novice teachers, and consistently less effective leadership (Branch, Hanushek, and Rivkin 2008; Condron and Roscigno 2003; Lankford, Loeb, and Wyckoff 2002).

\subsection{Effects of Principals on School Performance}

Leadership turnover may impact school outcomes because leadership itself can impact school outcomes. A range of studies provide evidence that leadership effects can work through a variety of mechanisms. These studies have assessed leaders' abilities to recruit high quality teachers, to motivate teachers, to articulate school vision and goals, to allocate resources and to develop organizational structures to support instruction and learning (Eberts and Stone 1988; Grissom and Loeb Forthcoming; Hallinger and Heck 1996; Harris, Rutledge, Ingle, and Thompson 2010; Horng, Klasik, and Loeb 2010; Jacob and Lefgren 2005; Leithwood, Louis, Anderson, and Wahlstrom 2004; Loeb, Kalogrides, and Béteille 2010). Strong school leadership is also likely to be an essential component of school improvement efforts (Bryk, Sebring, Allensworth, Luppescu, and Easton 2010).

Though logic suggests that principals are important for the performance of schools, it is less clear from prior research which observable attributes of principals are associated with high performance. Many prior studies that attempt to identify the effects of principal characteristics or behaviors on school performance fail to account for factors that confound that relationship 
(Ballou and Podgursky 1993; Brewer 1993; Eberts and Stone 1988; Hallinger and Heck 1996; Louis, Leithwood, Wahlstrom, and Anderson 2010). More effective schools may attract principals with different characteristics, even if those characteristics do not improve effectiveness. Simple correlations could mistakenly attribute cause to these correlational relationships.

Two recent studies have carefully examined the relationship between principal experience and school performance using district panel data and methods similar to ours (Branch, Hanushek, and Rivkin 2008; Clark, Martorell, and Rockoff 2009). These studies find a positive relationship between principal experience and student test scores. No studies, however, have rigorously examined the relationship between principal turnover and school outcomes. Though principal tenure at a school is partially a function of principal turnover (i.e., schools with high turnover rates employ principals with fewer years of school-specific experience), the two measures are conceptually distinct. The effect of turnover on school performance may be negative, in part, because it leads to a reduction in principal experience at schools that experience turnover. However, turnover could have negative effects on school performance independent from the relative inexperience of new principals to a school. Constant churning of principals in and out of schools can create instability that may undermine performance. That is, the instability created by principal turnover could have negative effects on school performance even if succeeding principals are identical in their skills and knowledge to the exiting principals they replace.

In this paper we use data from one of the largest public school districts in the United States to examine the consequences of leadership change on school performance. We begin by describing the principal labor market in this district, including rates of turnover from different 
types of schools and the characteristics of the schools to which principals transfer. We then examine the relationship between principal turnover and school-level outcomes and variations in the magnitude of these relationships in different types of schools. We find that principal turnover has negative effects on average achievement and particularly large negative effects on the achievement of students attending high poverty schools, those receiving failing grades within the state accountability system, and those with many first-year teachers. We conclude that principal preferences for easier to staff schools leads to considerable leadership turnover in schools with more disadvantaged students. These career pathways limit poor and low-achieving students' exposure to stable leadership, which negative affects their achievement.

\section{DATA}

The data used in this study come from administrative files on all staff, students, and schools in the Miami-Dade County Public Schools (M-DCPS) district from the 2003-04 through the 2008-09 school years. The school district we study, M-DCPS, is the largest public school district in Florida and the fourth largest in the United States, trailing only New York City, Los Angeles Unified, and the City of Chicago School District. In 2008, M-DCPS enrolled almost 352,000 students, more than 200,000 of whom were Hispanic. Nearly 90 percent of students in the district are either black or Hispanic and 60 percent qualify for free or reduced priced lunches. Over our observation period there are between 360 and 400 schools in the district. This provides ample power for identifying the effects of school characteristics (i.e., leadership turnover) on student and teacher outcomes. Basic descriptive information for the principals, teachers, and students that make up our sample is shown in Table 1.

The M-DCPS staff database includes demographic measures, prior experience in the district, current position, and highest degree earned for all district staff from the 2003-04 through 
the 2008-09 school years. We use this information to create five measures of principal experience and turnover in each year. The first measure tracks whether the school has a new principal in the current year. This measure captures only whether the principal is new to the school and not whether he or she has prior experience as a principal in other schools in the district. The second measure is whether the school has a first time new principal at their school. These principals have no prior principal experience as principals in the district. The third measure captures whether a school has a new principal who has previously served as principal at another school in the district. Distinguishing between these last two measures allows us to gauge whether achievement declines when schools are under the direction of a new principal because new principals have less experience. A fourth measure of experience tracks whether the school has a new principal who began with a temporary or interim status. Temporary/interim principals are usually appointed by the Superintendent to fill a vacancy which occurs as the result of an emergency situation — often in the middle of the school year. Finally, our fifth measure is a simple measure of school-specific experience which each principal's tenure at their current school.

We also use the staff-level data to examine the association between principal turnover and subsequent changes to teacher turnover. To examine teacher turnover following leadership transitions we use the staff database which allows us to observe teacher transfers between schools in the district as well as attrition from the district after any given year. These data also include teacher race, gender, highest degree earned, experience, and age which we use as control variables in our models.

In addition to these staff-level data, we have test score data and basic demographic information for all students in the district which we can link to classrooms (teachers) and to 
schools. The demographic variables include student race, gender, free/reduced price lunch eligibility, and whether students are limited English proficient. These variables serve as control variables in our models. The test score data include math and reading scores from the Florida Comprehensive Assessment Test (FCAT). The FCAT is given in math and reading to students in grades 3-10. It is also given in writing and science to a subset of grades, though we only use math and reading tests in our analyses. The FCAT includes criterion referenced tests measuring selected benchmarks from the Sunshine State Standards (SSS). We standardize students' test scores to have a mean of zero and a standard deviation of one within each grade and school-year.

\section{METHODS}

Our analysis includes three components: (1) we descriptively examine patterns of principal turnover in the district; (2) we identify the relationship between principal turnover and (a) teacher turnover and (b) student achievement; and (3) we describe variation in the relationship between principal turnover and school outcomes by school characteristics (poverty level, performance in the state accountability system, concentration of first-year teachers).

The second and third components of our analysis seek to isolate the effect of principal transitions on school outcomes, recognizing that principal turnover may be endogenous to other school characteristics. Schools with frequent principal turnover may differ from schools with more stable leadership in a variety of ways - they may have less stable teacher and student populations or other less favorable working conditions such as safety concerns, disciplinary problems, or insufficient resources. Such factors are likely to be negatively associated with school outcomes such as achievement. Though we do not have a perfect solution to this endogeneity problem, we seek to minimize the potential bias by including a rich set of control 
variables in all our models as well as school and/or student fixed effects. We also run analyses to uncover the likelihood of bias. We describe these approaches and their implications below.

\subsection{Teacher Turnover}

To examine the relationship between principal and teacher turnover we use data on all staff in the district and estimate a logistic regression predicting whether a teacher leaves their current school at the end of the year as a function of the measures of principal turnover and experience. In our full model we include controls for teacher characteristics (race, gender, highest degree, age, experience), time-varying school characteristics (percent receiving free/reduced priced lunches, percent minority, percent low achieving, enrollment), and school fixed effects. The types of schools that have high principal turnover may also have high teacher turnover with the former not necessarily causing the latter. We therefore prefer a model with school fixed effects since it shows the relationship between principal turnover and teacher turnover within the same school. That is, we are able to examine whether teacher turnover in a given school is higher in years that the school has a new principal compared to years that the school does not have a new principal. The model is estimated with the following equation:

$$
\begin{aligned}
& \operatorname{Pr}\left(T_{j s t}=1\right)=\frac{e^{f}}{1+e^{f}} \\
& \text { where } f=\beta_{0}+\beta_{1}(\text { New Principal })_{t s}+X_{s t} \beta_{2}+S_{t} \beta_{3}+\pi_{t}+\pi_{s}+\varepsilon_{j s t}
\end{aligned}
$$

The probability that teacher $j$ leaves their current school $s$ in year $t$ is a function of whether their school has a new principal in year $t$, teacher characteristics $\left(X_{s t}\right)$, time varying attributes of schools $\left(S_{t}\right)$, year fixed effects $\left(\pi_{t}\right)$ and school fixed effects $\left(\pi_{s}\right)$. In other models we replace the new principal variable with the other measures of principal turnover and experience discussed above.

\subsection{Student Achievement}


In order to examine the relationship between principal turnover and student achievement, we merge the principal database with our student data base. Given concerns about the endogeneity of principal turnover, we estimate specifications of our student achievement models that include school and/or student fixed effects. This approach allows us to discern whether students learn less in years that their schools have a new principal compared to how much students in the same school learn in other years when their school does not have a new principal.

The school fixed effect removes any stable characteristics of schools that may be associated with both the likelihood of principal turnover and lower student achievement. However, there may still be time-varying negative shocks that influence both turnover and achievement declines. While we do not have a perfect solution to this endogeneity problem, we use two approaches which reduce the potential for bias. First, in all models we control for the percentage of teachers at a school that are new in each year. If something bad happened at a school in the year before a new principal arrived, we expect that this will be absorbed by the teacher turnover rate. Second, as checks of the robustness of our estimates we include a control for the year before a new principal arrived in addition to the school fixed effect which takes out the average for the school across all years. If schools that experience a decrease in achievement in a given year are more likely to see their principal leave, then controlling for the year before the new principal arrives should account for this. Our estimates are generally unaffected by the inclusion of this measure or by the inclusion/exclusion of the teacher turnover rate.

Our estimates for the effect of principal turnover on student achievement are identified from students attending schools that experience at least one principal transition over the years in which they are tested. The following equation describes the model:

$$
A_{i s t}=\beta_{1} A_{i s(t-1)}+X_{i t} \beta_{2}+C_{t} \beta_{3}+S_{t} \beta_{4}+\beta_{5}\left(\text { NewPrincipal }_{t s}\right)+\pi_{i}+\pi_{s}+\pi_{t}+\varepsilon_{i s t}
$$


where the achievement of student $i$ in school $s$ in year $t$ is a function of their prior achievement $\left(A_{i s(t-1)}\right)$, time varying-attributes of students $\left(X_{i t}\right)$, their classes $\left(C_{t}\right)$ and their schools $\left(S_{t}\right)$, whether the student's school has a new principal (NewPrincipal ${ }_{t s}$ ), and student, school, and year fixed effects. The parameter of interest is $\beta_{5}$ which shows the difference in the average achievement of students in years when their school has a new principal compared to years in which they do not. In other models we replace the new principal variable with the other measures of principal turnover and experience discussed above.

\subsection{Interaction Models}

In the analyses described previously, we examine the average effect of principal turnover on school outcomes. However, we expect that the magnitude of this effect might depend on characteristics of schools. Certain types of schools may have higher rates of principal turnover and more difficulty attracting effective and experienced principals as successors. For example, if schools with high concentrations of poor or low achieving students attract less effective or experienced principals, then turnover might have larger negative effects in such schools.

To examine variation in the relationship between principal turnover and student achievement, we include interactions between school characteristics and whether the school has a new principal. We examine whether the effect of turnover is different for high poverty schools relative to lower poverty schools and whether the effect is different for failing schools (i.e., schools that receive an F grade from the Florida accountability system) relative to higher performing schools. ${ }^{2}$ We also expect that leadership turnover might be more consequential for

\footnotetext{
${ }^{2}$ School grades are determined by a formula used by the district that weighs the percentage of students meeting high standards across various subjects tested, the percentage of students making learning gains, whether adequate progress is made among the lowest 25 percent of students, and the percentage of eligible students who are tested. For more information, see: http://schoolgrades.fldoe.org/pdf/0708/2008SchoolGradesTAP.pdf
} 
schools that employ more novice teachers. Strong school leadership may be especially important for novice teachers who may benefit most from mentoring and support from their principal. Schools with a more stable senior teaching force may be better equipped to handle the departure of a principal since teachers in such schools are more familiar with their jobs and are likely to work more autonomously with less oversight from the school leadership. To examine whether the effects of principal turnover is different for schools with many novice teachers we include an interaction between whether the school has a new principal and a measure of whether the school is in the top quartile in terms of the percentage of their teachers who are in their first year.

\section{RESULTS}

We begin by describing principal turnover rates in M-DCPS as well as in several other school districts and professions for comparison purposes. Table 2 lists principal turnover rates as well as turnover rates for other managerial professions. In M-DCPS, 22 percent of principals leave their current school each year and most of those who leave transfer to another school in the district. The rates are similar in other districts: Milwaukee and North Carolina schools have annual turnover rates of around 20 percent, San Francisco has a turnover rate of 26 percent, New York City has a turnover rate of 24 percent, and Texas has a turnover rate of 30 percent. As Table 2 shows, in general, managerial turnover is fairly high in other professions as well ranging anywhere from 10 percent to 35 percent depending on the industry (Denis and Denis 1995; DiPrete and Krecker 1991; Fee and Hadlock 2004; Larsen 1993).

The turnover rate of principals varies across schools. Table 3 shows the principal turnover rate in M-DCPS for schools serving different student populations. The first column lists the total percentage of principals who left their current school at the end of the year, while the second and third columns separate exits via transfer to another school in the district from exits 
via attrition from the district. Principal turnover rates are highest in schools serving high concentrations of poor, minority and low achieving students. In M-DCPS, 28 percent of principals in schools in the top quartile of students receiving subsidized lunches (high poverty) leave each year compared to 18 percent of principals in schools in the bottom quartile (low poverty). Nearly 30 percent of principals in schools with high concentrations of low achieving students leave each year compared to only 16 percent of principals in schools with low concentrations of low achieving students. We find similar results in Milwaukee and San Francisco from which we also have data (not shown), as do Gates et al. (2004) in their study of North Carolina and Ringel et al. (2004) in their study of Illinois.

\subsection{Are Principals More Likely to Leave Following a Year of Poor Performance?}

Prior studies of leadership turnover in other professions have found that leaders are more likely to leave following a period of poor performance (Allen, Panian, and Lotz 1979; Brown 1982; Denis and Denis 1995). We examine whether principal exits are associated with the performance of their school by predicting student test score gains in a given year as a function of whether a school's principal leaves at the end of that year. We also separate principal exists via transfer and via attrition. The results are shown in Table 4. The coefficients are all essentially zero and not statistically significant. This suggests that poor school performance is not, on average, a precursor to principal turnover. This analysis also suggests that schools that experience principal exits are not necessarily experiencing a downward achievement trajectory which could confound our estimates of the effect of turnover on student achievement.

Since the majority of principal turnover results from principals transferring schools within the district, we next turn to an analysis of principals' school preferences and transfer patterns. In Table 5 we compare the characteristics of principals' current schools with the 
characteristics of the schools they report they would most like to work in. The self-report data come from a survey of principals in Miami that we administered in $2010 .{ }^{3}$ We asked principals if they could work in any school in the district (other than their current school) which would be their first choice. We compare the characteristics of the student bodies in their current school with their first choice school. The results show that principals' first choice schools have fewer poor, black and low achieving students than their current school as well as fewer students who are suspended or chronically absent.

Principals' stated preferences mirror their actual transfer patterns. We compare the characteristics of principals' initial schools to the characteristics of the schools to which they transfer in Table 6. There is one observation for each principal-school combination and we predict a school characteristic as a function of whether the school is the principals' first, second, third, or fourth or more school. The models also include a principal fixed effect. Principals' first school is the omitted category, thus the coefficients show the difference in school characteristics between a principal's first school and each subsequent school. The models are only identified from principals who serve at more than one school. The results from these analyses show that principals who transfer tend to move to schools with higher achieving students, fewer poor students, fewer minority students, and fewer students with attendance problems. For example, principals' second and third schools have about 9 percent fewer low achieving students than their first schools, 4 percent more high achieving students than their first schools, 8-9 percent fewer poor and minority students than their first school and 3-6 percent fewer students who are chronically absent. Few principals serve at four or more schools during our observation period so those coefficients are less precisely estimated. These results are consistent with principals' reports of their school preferences.

\footnotetext{
${ }^{3}$ We administered an online survey to all principals in M-DCPS in May of 2010 with a response rate of 55 percent.
} 
Taken together, the results presented thus far suggest that principals are not leaving when their school is performing poorly but, rather, they tend to leave when vacancies arise at easier to staff schools given that they find such schools more appealing.

\subsection{Principal Turnover and School Outcomes}

Next, we turn to an examination of the relationship between principal turnover and both teacher turnover (Table 7) and student achievement (Tables 8 and 9). We run two models for each analysis. The first model includes a detailed set of control variables and shows whether the outcome differs in schools and years when there is a new principal in comparison to similar schools and years. ${ }^{4}$ The second model includes school fixed effects asking whether within a school the outcome differs in years where there is a new principal compared to years when there is not a new principal. While the last specification is the cleanest causally, it identifies the effect only from the small variation within schools across years. Tables 8 and 9 include one additional model that adds a student fixed effect to the model with school fixed effects and the controls.

In Table 7 we find that turnover among teachers is higher when a new principal takes over at a school. The first row of the Table shows that the odds that a teacher leaves his or her current school are about 17 percent higher in years and schools that have a new principal. The direction of the results remains in the next two models which aim to identify the causal effect of principal turnover on teacher turnover. Within schools, the odds of teacher turnover are approximately 8.7 percentage points higher in the years in which there is a new principal. These results are marginally significant and not substantially different from the model with controls

\footnotetext{
${ }^{4}$ The control variables used in our teacher turnover models include: race, gender, age, age ${ }^{2}$, highest degree earned, experience (entered as dummies and top coded at 21 or more years), percentage of students receiving free/reduced priced lunches at the school, percent minority at the school, logged school enrollment, average math achievement at the school and year fixed effects. The control variables used in our student achievement models include: prior achievement, race, gender, whether the student is limited English proficient, free/reduced priced lunch receipt, whether the student was retained in the prior year, school and class percentage free/reduced priced lunches, limited English proficient and average prior achievement as well as year and grade fixed effects.
} 
instead of fixed effects (11.3 percentage points) which is strongly statistically significant and has greater statistical power.

Teacher turnover might be higher in years when schools have a new principal because of the relative inexperience of new principals. More experienced principals might be more skilled in developing effective policies to retain their teachers or supporting a collegial environment that curbs turnover. In addition, a new principal might be more likely than a more experienced principal to bring a new approach to the school that is in conflict with teachers' preferences; thus causing teachers to seek other positions. In the second panel of Table 7 we add a control for the number of prior years of experience that the principal has as a principal in any school. Controlling for this measure reduces the magnitude of the new principal effect on turnover somewhat but there is still a significant positive relationship between principal and teacher turnover in the model with control variables (model 2). This result suggests that the lack of experience of a new principal to a school explains some but not all of the positive relationship between principal and teacher turnover. The final model that includes school fixed effects does not show a significant relationship but most of the difference between models 2 and 3 comes from an increase in the standard error, likely due to the substantially reduced variation when we include school fixed effects.

Another way of gauging the importance of experience in explaining the relationship between principal and teacher turnover is to distinguish between cases when the new principal is a first time new principal and cases when the new principal has prior experience as a principal in another school. This analysis is shown in the third panel of Table7. The relationship appears somewhat stronger for new principals with prior experience than for new principals without prior experience, though the differences are not statistically significant in any of the specifications. 
The similarity in the magnitude of the effects of having a new first time principal and a new principal with prior experience at another school suggests that whether the new principal is experienced or not is not an important influence on teacher turnover. Taken together these results suggest that leadership instability tends to generate greater instability among the teaching force that goes beyond the turnover associated with having a less experienced principal.

The final two panels of Table 7 give estimates of the effects of having a temporary or interim principal and of principal experience on teacher attrition. We see that on average teachers turn over more under temporary or interim principals but that this relationship is small (3.6 percent in the model with controls and 1.6 percent in the school fixed effects model) and not statistically different from zero. The final panel shows that teachers are less likely to leave under principals with longer tenure at their school. An extra year of experience at a school is associated with a 4 percentage point reduction in the odds of turnover in the school fixed effects model, but these estimates are not statistically significant.

In Table 8 (math) and Table 9 (reading) we examine the relationship between principal turnover and student achievement. Model 1 includes a measure of lagged achievement, the percentage of new teachers at the school, student, school, and classroom control variables as well as grade and year fixed effects. Model 2 adds a school fixed effect and model 3 adds a student fixed effect. We focus our discussion on models 2 and 3 since they bring us closest to identifying a causal effect of principal turnover on achievement. These models use variation in the presence of new leaders within schools (across time) to examine whether students learn less in years when their school has a new principal compared to years when their school does not have a new principal. 
The effects are relatively small but consistent across models and outcome measures. In Table 8 we find that students make lower achievement gains in math when their school has a new principal (first panel), when their school has a new first time principal (without prior experience in another school) (third panel), and when their school has a temporary or interim principal (fourth panel). Students also have higher learning gains in math when their principal has longer tenure at their school (fifth panel). Interestingly, there is no negative effect on math achievement when a school has a new principal who previously served as a principal at another school in the district (third panel). This suggests that the skills and experience that principals bring to their new schools are important and that lack of prior experience explains much of the negative effect of turnover on math achievement.

One concern with these models is that schools that are on a downward achievement trajectory might also be more likely to experience principal turnover, which could potentially bias our estimates. We account for this possibility in the second panel by controlling for the year prior to the new principal (similar to the analysis shown in Table 4). Our estimates of the effect of having a new principal on math achievement remain relatively unchanged with the inclusion of this control.

The results for reading achievement in Table 9 are fairly similar to those discussed for math thus far. We see a negative relationship between achievement and having a new principal and we see a positive relationship between achievement and principal experience at the school. On the other hand, for reading the effect of having a new principal with prior experience is just as negative as having a new principal without prior experience and we do not find a negative effect for temporary or interim principals. 
In the sixth panel of Tables 8 and 9 we add interactions between years of prior principal experience and the new principal indicator. This principal experience measure reflects years of experience in any school in the district and is distinct from the measure of experience used in panel five of Tables 8 and 9, which only captures years of experience at the current school. For math (Table 8) the main effect on new principal in model 4 suggests that student achievement is about .013 standard deviations lower when schools have a new principal without any prior principal experience (i.e., when prior years of experience is equal to zero). However, the interaction between new principal and prior principal experience is positive and statistically significant. This suggests that the negative effect of having a new principal is smaller when new principals to a school have more prior experience serving as a principal in other schools. The results for reading achievement in Table 9 are a bit different. These results suggest that overall years of principal experience is positively related to reading achievement and the magnitude of that relationship is similar or slightly smaller in schools with a new principal. Though the negative interaction term in models 1 and 2 suggests that principal experience is less important in schools with a new principal, the interactions are still smaller than the main effect on principal experience suggesting that principal experience is still related to reading achievement in schools with new principals. These results suggest that principal experience is important in schools with new principals and that the negative effect of leadership turnover on student achievement can be mitigated through the recruitment of experienced succeeding principals.

In sum, we find that principal turnover is positively associated with teacher turnover and negatively associated with student achievement. These results provide fairly consistent evidence that greater instability among leadership is detrimental to school outcomes and that new 
principals without any prior experience seem to be less effective than their more experienced counterparts.

\subsection{Interaction Models}

In our final set of analyses we examine whether the association between leadership changes and student achievement is different in low performing schools, high poverty schools, and in schools with high concentrations of novice teachers. In Table 10 we predict student achievement as a function of our full set of student, school, and classroom controls as well as the relevant fixed effects. In models 1 and 2 we include a variable indicating whether the school received a failing accountability grade (i.e., an " $F$ " grade) in the prior year as well as an interaction between whether the school had a new principal in the current year and earned a failing grade in the prior year. In models 3 and 4 we include a variable indicating whether the school was in the top quartile of students receiving subsidized lunches (high poverty) and an interaction between this variable and whether the school has a new principal. In models 5 and 6 we include a variable indicating that the school was in the top quartile in terms of their proportion of first-year teachers and interact this variable with the new principal indicator. We are interested in the interaction terms in these models since they show whether principal turnover is more consequential for students attending failing schools, high poverty schools, or schools with many first-year teachers. We also estimate these models using a measure of principal experience at a school in lieu of the new principal indicator.

The negative relationship between principal turnover and math and reading achievement is stronger in failing schools and in high poverty schools. The negative effect of principal turnover on math achievement is also larger in schools with high concentrations of novice teachers, though we do not find similar effects for reading achievement. Here we focus our 
discussion of the models with student fixed effects (models 2, 4, and 6) though most of these results are similar in models that exclude them (models 1,3 , and 5). While there is little or no relationship between having a new principal and achievement in non-poor schools, higher performing schools, or schools with fewer novice teachers (shown by the main effects), students in failing schools have reading and math achievement that is about .04-.06 standard deviations lower in years when they have a new principal, students in high poverty schools have reading and math achievement that is .02-.03 standard deviations lower in years when they have a new principal, and students in schools with high concentrations of novice teachers have math achievement that is about .02 standard deviations lower in years when they have a new principal. Similarly, principal tenure at a school bears a stronger relationship to achievement gains in high poverty schools, failing schools, and schools with high concentrations of novice teachers than in more advantaged and higher performing schools. Instability among school leadership is therefore more consequential for high poverty and failing schools, schools which also tend to have more frequent turnover.

The effect of turnover may be different for high poverty and failing schools if such schools differ in their ability to attract experienced successors. We examine this descriptively in Table 11, which shows the characteristics of new principals in different types of schools. We list the proportion of new principals with prior experience, years of prior principal experience in the district, and the proportion of principals with master's degrees. As expected, new principals in high poverty schools have less prior experience as a principal and are less likely to have a master's degree or higher compared to new principals in schools with fewer low-income students. About 65 percent of new principals in low poverty schools have previously served as principal at another school in the district compared to only 30 percent of new principals in high 
poverty schools. Similarly, new principals in high poverty schools have about half as many prior years experience as principals in low poverty schools (roughly 4 versus 2 years). New principals in high poverty schools are also less likely to have a masters degree (65 percent in low poverty schools compared to 56 percent in high poverty schools). Therefore, the effect of having a new principal may be more negative for high poverty schools because such schools are unable to attract the most experienced and credentialed successors.

\section{DISCUSSION}

Many school districts throughout the country—including the district studied in this paper-face high rates of principal turnover (Branch, Hanushek, and Rivkin 2008; Gates, Ringel, Santibanez, Ross, and Chung 2003; Papa, Lankford, and Wyckoff 2002b). While turnover averages approximately 20 percent in the district we study as a whole, it is about a third higher in schools with high concentrations of poor, minority and low achieving students. Though we do not have data on why principals choose to leave their schools, we find evidence that suggests that one likely reason is a desire to move to easier to staff schools. When asked via a survey, principals indicate that they would prefer to work at a school that is higher achieving than the school in which they are currently employed. Those who switch schools tend to move to schools with fewer students in poverty and fewer low achieving students compared to where they start. This is consistent with previous work studying principals' preferences for schools (Loeb, Kalogrides, and Horng 2010).

Schools are not the only type of organization that experiences voluntary turnover-for example, managers may also move among similar firms in the for-profit sector. However, schools are more constrained than private firms in the resources they can deploy to keep effective employees. Given the rigidities of the salary schedule for teachers and school 
administrators in most districts, there are few opportunities to increase one's earnings outside of acquiring more experience or further credentials. The career trajectories of school personnel therefore may be more affected by non-pecuniary benefits such as positive working conditions than are other workers (Hanushek, Kain, and Rivkin 2004; Lankford, Loeb, and Wyckoff 2002; Loeb, Kalogrides, and Horng 2010).

Since much of the turnover we document is likely to be voluntary and driven by a preference to move to easier to serve schools, it is not surprising that we find no evidence of a relationship between school performance and the likelihood that a principal leaves a school. While some principals whose schools are performing poorly may leave either via termination or by their own accord, some principals whose schools are performing well also leave. A proven track record in improving the performance of a school is likely to make a principal a viable candidate for vacancies in other, more appealing schools. Prior research on the effects of leadership turnover on organizational performance suggests that turnover can be beneficial in instances where ineffective leaders are replaced (Grusky 1963; Virany, Tushman, and Romanelli 1992). But the dynamics of the principal labor market we document suggest that the majority of turnover is not driven by an attempt to replace ineffective leaders.

The consequences of the turnover we document are clearly negative, on average. There are a variety of possible explanations for these negative effects and we do not distinguish them in this paper. For example, others have hypothesized that turnover may undermine reform efforts and reduce employee buy-in, fracture professional networks developed among employees and leadership, create unclear goals and expectations, and make for a less stable and desirable working environment (Abelson and Baysinger 1984; Fuller and Young 2009; Hallinger and Heck 1996; Steinberg 2000). These disruptive effects of turnover for schools could be cause for 
concern, particularly in high poverty and failing schools where turnover rates are quite high and the negative effects of turnover are large. Our results suggest that practices that bring in experienced (and effective) administrators can mitigate some of the problems created by turnover. Turnover's negative effects are smaller when vacancies are filled with principals who have prior experience leading other schools in the district. At the same time, the types of schools that hire less experienced new principals (i.e., high poverty schools) tend to suffer more harm from leadership instability.

Turnover might have less detrimental effects on more advantaged schools because they have less frequent turnover and because they attract more experienced replacements. It is also possible that principals matter less in these schools - these schools have more advantaged and higher achieving students and likely have an easier time attracting strong teachers. Turnover in these schools might also occur more often from retirement rather than a desire to move to an easier to serve school. In instances where the principal's exit is anticipated (i.e., due to retirement) there might be more mechanisms in place to ensure a smoother transition. Overall, our results suggest that principals' desire to work in schools with more affluent and high achieving students reduces disadvantaged students' exposure to experienced and stable school personnel (both teachers and principals) which has negative consequences for their learning. 


\section{REFERENCES:}

Abelson, Michael A. and Barry D. Baysinger. 1984. "Optimal and Dysfunctional Turnover: Toward an Organizational Level Model." The Academy of Management Review 9:331341.

Allen, Michael Patrick, Sharon K. Panian, and Roy E. Lotz. 1979. "Managerial Succession and Organizational Performance: A Recalcitrant Problem Revisited." Administrative Science Quarterly 24:167-180.

Audas, Rick, Stephen Dobson, and John Goddard. 2002. "The Impact of Managerial Change on Team Performance in Professional Sports." Journal of Economics and Business 54:633650.

Azoulay, Pierre, Joshua Graff Zivin, and Jialan Wang. 2010. "Superstar Extinction." Quarterly Journal of Economics 25:549-589.

Ballou, Dale and Michael J. Podgursky. 1993. "What Makes a Good Principal? How Teachers Assess the Performance of Principals." Economics of Education Review 14:243-52.

Branch, Gregory F., Eric A. Hanushek, and Steven G. Rivkin. 2008. "Principal turnover and effectiveness." in Meetings of the American Economics Association San Francisco, CA.

Brewer, Dominic J. 1993. "Principals and Student Outcomes: Evidence from U.S. High Schools." Economics of Education Review 12:281-292.

Brown, M. C. 1982. "Administrative Succession and Organizational Performance- The Succession Effect." Administrative Science Quarterly 27:1-16.

Bryk, Anthony, Penny Bender Sebring, Elaine Allensworth, Stuart Luppescu, and John Q. Easton. 2010. Organizing Schools for Improvement: Lessons from Chicago. Chicago, IL: University of Chicago Press. 
Clark, Damon, Paco Martorell, and Jonah Rockoff. 2009. "School Principals and School Performance." National Center for Analysis of Longitudinal Data in Education Research.

Condron, Dennis J. and Vincent J. Roscigno. 2003. "Disparities within: Unequal Spending and Achievement in an Urban School District." Sociology of Education 76:18-36.

DeAngelis, Karen J. and Bradford R. White. 2011. "Principal Turnover in Ilinois Public Schools, 2001-2008." Illinois Education Research Council.

Denis, David J. and Diane K. Denis. 1995. "Performance Changes Following Top Management Dismissals." The Journal of Finance 50:1029-1057.

Dillon, Sam. 2011. "U.S. Plan to Replace Principals Hits Snag: Who Will Step In?" in New York Times. New York.

DiPrete, Thomas A. and Margaret L. Krecker. 1991. "Occupational Linkages and Job Mobility within and across Organizations." Research in Social Stratification and Mobility 10:91131.

Eberts, Randall W. and Joe A. Stone. 1988. "Student Achievement in Public Schools: Do Principals Make a Difference?" Economics of Education Review 7:291-299.

Eitzen, D.Stanley and Norman R. Yetman. 1972. "Managerial Change, Longevity, and Organizational Effectiveness." Administrative Science Quarterly 17:110-116.

Fee, Edward C. and Charles J. Hadlock. 2004. "Management Turnover Across the Corporate Hierarchy." Journal of Accounting and Economics 37:3-38.

Fuller, Ed and Michelle D. Young. 2009. "Tenure and Retention of Newly Hired Principals in Texas." University Council for Educational Administration, Austin, Texas.

Gamson, William A. and Norman A. Scotch. 1964. "Scapegoating in Baseball." American Journal of Sociology 70:69-72. 
Gates, Susan M., Jeanne S. Ringel, Lucrecia Santibanez, Cassandra Guarino, Bonnie GhoshDastidar, and Abigail Brown. 2005. "Mobility and Turnover among School Principals." Economics of Education Review 25:289-302.

Gates, Susan M., Jeanne S. Ringel, Lucrecia Santibanez, Karen E. Ross, and Catherine H.

Chung. 2003. "Who is Leading Our Schools? An Overview of School Administrators and Their Careers." RAND Santa Monica.

Grissom, Jason and Susanna Loeb. Forthcoming. "Triangulating Principal Effectiveness: How Perspectives of Parents, Teachers, and Assistant Principals Identify the Central Importance of Managerial Skills." American Educational Research Journal Available Online: http://aer.sagepub.com/content/early/2011/03/26/0002831211402663.full.pdf+html.

Grusky, Oscar. 1960. "Administrative Succession in Formal Organizations." Social Forces 39:105-115.

Grusky, Oscar. 1963. "Managerial Succession and Organizational Effectiveness." American Journal of Sociology 69:21-31.

Hallinger, Philip and Ronald H. Heck. 1998. "Exploring the principal's contribution to school effectiveness: 1980-1995." School Effectiveness and School Improvement 9:157-191.

Hallinger, Phillip and Ronald H. Heck. 1996. "Reassessing the Principal's Role in School Effectiveness: A Review of Empirical Research, 1980-1995." Educational Administration Quarterly 32:5-44.

Hanushek, Eric, John F. Kain, and Steven G. Rivkin. 2004. "Why Public Schools Lose Teachers." Journal of Human Resources 39:326-354. 
Harris, Douglas N., Stacey A. Rutledge, William K. Ingle, and Cynthia C. Thompson. 2010. "Mix and Match: What Principals Look for when Hiring Teachers and Implications for Teacher Quality Policies." Education Finance and Policy 5:228-246.

Horng, Eileen. 2009. "Teacher Tradeoffs: Disentangling Teachers' Preferences for Working Conditions and Student Demographics." American Educational Research Journal 46:690-717.

Horng, Eileen, Daniel Klasik, and Susanna Loeb. 2010. "Principal's Time Use and School Effectiveness." American Journal of Education 116:491-523.

Jacob, Brian A and Lars Lefgren. 2005. "Principals As agents: Subjective performance measurement in education." in NBER Working Paper Series. Cambridge: NBER.

Lankford, Hamilton, Susanna Loeb, and James Wyckoff. 2002. "Teacher Sorting and the Plight of Urban Schools: A Descriptive Analysis." Educational Evaluation and Policy Analysis 24:37-62.

Larsen, P.D. 1993. "Factors Influencing Retention of Directors of Nursing at Rural Long-Term Care Facilities. What Difficulties do Rural LTC Facilities Face in Attracting and Retaining Qualified NA/DONs?" Geriatric Nursing 14:261-264.

Leithwood, Kenneth, Karen Seashore Louis, Stephen Anderson, and Kyla Wahlstrom. 2004. "How leadership influences student learning." Learning from Leadership Project, Minneapolis, MN.

Loeb, Susanna, Demetra Kalogrides, and Tara Béteille. 2010. "Effective Schools: Teacher Hiring, Assignment, Development, and Retention." Cambridge: National Bureau of Economic Research, Working Paper \#17177. 
Loeb, Susanna, Demetra Kalogrides, and Eileen Horng. 2010. "Principal Preferences and the Unequal Distribution of Principals Across Schools." Education Evaluation and Policy Analysis 32:205-229.

Loeb, Susanna and Michelle Reininger. 2004. "Public Policy and Teacher Labor Markets: What we Know and Why it Matters." The Education Policy Center at Michigan State University, East Lansing.

Louis, Karen Seashore, Kenneth Leithwood, Kyla L. Wahlstrom, and Stephen E. Anderson. 2010. "Learning from Leadership Project: Investigating the Links to Improved Student Learning." Center for Applied Research and Educational Improvement.

Mobley, William. 1982. "Some Unanswered Questions in Turnover and Withdrawal Research." The Academy of Management Review 7:111-116.

Papa, Frank C., Hamilton Lankford, and James Wyckoff. 2002a. "The Attributes and Career Paths of Principals: Implications for Improving Policy." Teacher Policy Research Center. Papa, Frank C., Hamilton Lankford, and James Wyckoff. 2002b. "The attributes and career paths of principals: Implications for improving policy." University at Albany, SUNY, New York.

Pfeffer, Jeffrey and Alison Davis-Blake. 1986. "Administrative Succession and Organizational Performance: How Administrator Experience Mediates the Succession Effect." The Academy of Management Journal 29:72-83.

Ringel, Jeanne, Susan Gates, Catherine Chung, Abigail Brown, and Bonnie Ghosh-Dastidar. 2004. "Career Paths of School Administrators in Illinois: Insights from an Analysis of State Data." RAND, Santa Monica, CA. 
Roza, Marguerite. 2003. "A Matter of Definition: Is There Truly a Shortage of School Principals." Center on Reinventing Public Education, University of Washington.

Smith, Jonathan E., Kenneth P. Carson, and Ralph A. Alexander. 1984. "Leadership: It Can Make a Difference." The Academy of Management Journal 27:765-776.

Steinberg, Jacques. 2000. "Nation's Schools Struggling to Find Enough Principals." in New York Times, vol. September 3, 2000. New York City.

Tucker, Jill. 2010. "5 S.F. School Principals Under Fire." in San Francisco Chronicle. San Francisco.

U.S. Department of Education. 2010. "Guidance on Fiscal Year 2010 School Improvement Grants." Wasington, D.C.

Virany, Beverly, Michael L. Tushman, and Elaine Romanelli. 1992. "Executive Succession and Organizational Outcomes in Turbulent Environments: An Organizational Learning Approach." Organization Science 3:72-91.

Weinstein, Meryle, Robin Jacobowitz, Todd Ely, Kate Landon, and Amy Ellen Schwartz. 2009. "New Schools, New Leaders: A Study of Principal Turnover and Academic Achievement at New High Schools in New York City." The Institute for Education and Social Policy, New York University. 
Table 1. Descriptive Statistics

\begin{tabular}{|c|c|c|}
\hline & Mean & SD \\
\hline \multicolumn{3}{|l|}{ Principal Characteristics } \\
\hline Total Years of Experience in District & 22.37 & 8.14 \\
\hline Years Experience as Principal & 3.88 & 3.61 \\
\hline White & 0.26 & \\
\hline Black & 0.36 & \\
\hline Hispanic & 0.38 & \\
\hline Female & 0.67 & \\
\hline Masters Degree or Higher & 0.70 & \\
\hline Total Principal Observations & 2041 & \\
\hline Percentage of Principals who Serve Two or More Schools & 0.35 & \\
\hline Percentage of Principals who Serve Three or More Schools & 0.10 & \\
\hline \multicolumn{3}{|l|}{ Teacher Characteristics } \\
\hline Total Yearsof Experience in District & 9.55 & 9.29 \\
\hline White & 0.28 & \\
\hline Black & 0.27 & \\
\hline Hispanic & 0.43 & \\
\hline Female & 0.76 & \\
\hline Age & 42.23 & 11.72 \\
\hline Master's Degree or Higher & 0.40 & \\
\hline Total Teacher Observations (all teachers) & 102646 & \\
\hline \multicolumn{3}{|l|}{ Student Characteristics } \\
\hline Black & 0.27 & \\
\hline Hispanic & 0.60 & \\
\hline Female & 0.49 & \\
\hline Limited English Proficient & 0.16 & \\
\hline Retained in Year Prior & 0.04 & \\
\hline Eligible for Subsidized Lunch & 0.61 & \\
\hline Total Student Observations (all students) & 2145115 & \\
\hline Total Student Observations (with test scores) & 1246335 & \\
\hline
\end{tabular}


Table 2. Principal Turnover Rates in Various School Districts and Comparisons with Turnover Rates in Other

Leadership Professions

\begin{tabular}{|c|c|c|c|c|}
\hline Source & Profession & School District(s) & Time Period & Annual Turnover Rate \\
\hline \multicolumn{5}{|l|}{ PRINCIPALS } \\
\hline $\begin{array}{l}\text { Authors' calculations from data } \\
\text { provided by district }\end{array}$ & Principals & $\begin{array}{c}\text { Miami-Dade County } \\
\text { Public Schools } \\
\end{array}$ & 2003-2009 & $\begin{array}{l}22 \% \text { (Total); } 16 \% \\
\text { (Transfer); 6\% (Attrit) } \\
\end{array}$ \\
\hline $\begin{array}{l}\text { Authors' calculations from data } \\
\text { provided by district }\end{array}$ & Principals & $\begin{array}{c}\text { Milwaukee Public } \\
\text { Schools } \\
\end{array}$ & $2000-2008$ & $\begin{array}{l}\text { 19\% (Total); 11\% } \\
\text { (Transfer); 8\% (Attrit) }\end{array}$ \\
\hline $\begin{array}{l}\text { Authors' calculations from data } \\
\text { provided by district }\end{array}$ & Principals & $\begin{array}{c}\text { San Francisco Unified } \\
\text { School District }\end{array}$ & 2003-2009 & $\begin{array}{l}\text { 26\% (Total); 18\% } \\
\text { (Transfer); 8\% (Attrit) }\end{array}$ \\
\hline $\begin{array}{l}\text { Authors' calculations from data } \\
\text { provided by district }\end{array}$ & Principals & New York City & 1999-2008 & $24 \%$ (Total) \\
\hline Papa, Lankford, Wyckoff (2002) & First Time Principals & New York State & 1992 & $36 \%$ (Total) \\
\hline Gates et al. (2004) & Principals & North Carolina State & 1987-2001 & $\begin{array}{l}\text { 18\% (Total); 9\% } \\
\text { (Transfer); 9\% (Attrit) }\end{array}$ \\
\hline Ringel et al. (2004) & Principals & Illinois State & 1987-2001 & $\begin{array}{l}\text { 14\% (Total); } 7 \% \\
\text { (Transfer); 7\% (Attrit) }\end{array}$ \\
\hline DeAngelis and White (2011) & Prinicpals & Illinois State & 2001-2008 & $20 \%$ (Total) \\
\hline $\begin{array}{l}\text { Branch, Hanushek, and Rivkin } \\
\text { (2009) }\end{array}$ & Principals & Texas State & $1995-2001$ & $30 \%$ (Total) \\
\hline Steinberg (2000) & Principals & Washington State & 1999 & $15 \%$ (Attrit) \\
\hline \multicolumn{5}{|c|}{ OTHER LEADERSHIP PROFESSIONS } \\
\hline DiPrete and Krecker (1991) & $\begin{array}{c}\text { Professional and } \\
\text { Managerial Workers }\end{array}$ & --- & $1980 \mathrm{~s}$ & $10 \%$ \\
\hline Sorensen (2000) & TV Station Supervisors & --- & $1953-1988$ & $15 \%$ \\
\hline Audas et al. (1999) & English Soccer Coaches & --- & 1972-1999 & $36 \%$ \\
\hline Pfeffer and Davis-Blake (1986) & $\begin{array}{l}\text { National Basketball } \\
\text { Association Coaches }\end{array}$ & --- & $1977-1981$ & $25 \%$ \\
\hline Fee and Hadlock (2000) & Newspaper Managers & --- & $1950-1993$ & $15-16 \%$ \\
\hline Allen, Panian, and Lotz (1979) & $\begin{array}{c}\text { Major League Baseball } \\
\text { Coaches } \\
\end{array}$ & --- & $1920-1973$ & $36 \%$ \\
\hline Denis and Denis (1995) & CEOs & $\overline{---}$ & $1985-1988$ & $22 \%$ \\
\hline Larsen (1993) & Nurse Managers & --- & 1993 & $35 \%$ \\
\hline
\end{tabular}


Table 3. Average Annual Principal Turnover Rate by School Type in Miami-Dade County Public Schools

\begin{tabular}{lccc}
\hline & $\begin{array}{c}\text { Total \% } \\
\text { Left }\end{array}$ & $\begin{array}{c}\text { \% } \\
\text { Transfer }\end{array}$ & $\begin{array}{c}\text { \%trit } \\
\text { Attrit }\end{array}$ \\
\hline All Schools & $22 \%$ & $16 \%$ & $5 \%$ \\
Percent Free Lunch & & & \\
Quartile 1 & $18 \%$ & $12 \%$ & $5 \%$ \\
Quartile 4 & $28 \%$ & $21 \%$ & $6 \%$ \\
Percent Minority & & & \\
Quartile 1 & $20 \%$ & $14 \%$ & $5 \%$ \\
Quartile 4 & $28 \%$ & $23 \%$ & $4 \%$ \\
Percent Low Achieving(Math) & & & \\
Quartile 1 & $16 \%$ & $9 \%$ & $6 \%$ \\
Quartile 4 & $29 \%$ & $22 \%$ & $6 \%$ \\
Percent Being Suspended & & & \\
Quartile 1 & $19 \%$ & $12 \%$ & $7 \%$ \\
Quartile 4 & $27 \%$ & $22 \%$ & $5 \%$ \\
Percent Absent 21 or More Days & & & \\
Quartile 1 & $17 \%$ & $10 \%$ & $6 \%$ \\
Quartile 4 & $27 \%$ & $22 \%$ & $5 \%$ \\
School Accountability Grade & & & \\
A & $19 \%$ & $13 \%$ & $6 \%$ \\
B & $20 \%$ & $14 \%$ & $5 \%$ \\
C & $26 \%$ & $20 \%$ & $6 \%$ \\
D & $25 \%$ & $19 \%$ & $6 \%$ \\
F & $48 \%$ & $43 \%$ & $5 \%$ \\
School Level & & & \\
Elementary & $21 \%$ & $16 \%$ & $5 \%$ \\
Middle & $23 \%$ & $18 \%$ & $4 \%$ \\
High & $25 \%$ & $20 \%$ & $4 \%$ \\
\hline
\end{tabular}

Notes: Transfer refers to the percentage of principals who transfer to another school in the district at the end of an academic year. Attrition refers to the percentage of principals who are no longer observed as a principal in the district following the end of an academic year. 
Table 4. Relationship between Student Achievement and Principal Turnover

\begin{tabular}{lcc}
\hline & Math & Reading \\
\hline$\underline{\text { Model 1 }}$ & & \\
Year Prior to Principal Exit & -0.001 & 0.000 \\
& $(0.004)$ & $(0.003)$ \\
\hline$\underline{\text { Model 2 }}$ & & \\
Year Prior to Principal Exit (via Attrition) & 0.001 & 0.001 \\
& $(0.006)$ & $(0.005)$ \\
Year Prior to Principal Exit (via Transfer) & -0.003 & 0.000 \\
& $(0.005)$ & $(0.004)$ \\
\hline Control for Lag of Outcome & $\mathrm{X}$ & $\mathrm{X}$ \\
Time-Varying Student Controls & $\mathrm{X}$ & $\mathrm{X}$ \\
Time-Varying School Controls & $\mathrm{X}$ & $\mathrm{X}$ \\
Time-Varying Classroom Controls & $\mathrm{X}$ & $\mathrm{X}$ \\
School Fixed Effect & $\mathrm{X}$ & $\mathrm{X}$ \\
Grade Fixed Effect & $\mathrm{X}$ & $\mathrm{X}$ \\
Year Fixed Effect & $\mathrm{X}$ & $\mathrm{X}$ \\
Clustered Standard Errors (by School-Year) & $\mathrm{X}$ & $\mathrm{X}$ \\
\hline Notes: + pr.10*p<.05, & & \\
\hline
\end{tabular}

Notes: $+\mathrm{p}<.10^{*} \mathrm{p}<.05,{ }^{* *} \mathrm{p}<.01,{ }^{* * *} \mathrm{p}<.001$ 
Table 5. Comparison of School Characteristics- Principals' Current School and Other Schools they Would Like to Work In

\begin{tabular}{lccc}
\hline & Current & First Choice & Difference \\
& School (A) & School (B) & (A-B) \\
\hline Percent F/R Lunch & 0.73 & 0.68 & 0.05 \\
Percent Black & 0.30 & 0.24 & 0.06 \\
Percent Lowest Achievement Level in Math & 0.19 & 0.11 & 0.08 \\
Percent Highest Achievement Level in Math & 0.09 & 0.12 & -0.03 \\
Percent Lowest Achievement Level in Reading & 0.25 & 0.18 & 0.07 \\
Percent Highest Achievement Level in Reading & 0.07 & 0.09 & -0.02 \\
Standardized Math Score & -0.14 & 0.09 & -0.23 \\
Standardized Reading Score & -0.12 & 0.09 & -0.21 \\
Percent Students Suspended this Year & 0.08 & 0.05 & 0.03 \\
Percent Students Chronically Absent this Year & 0.10 & 0.06 & 0.04 \\
\hline Notes: Figures are from a 2010 survey of principals in Miami-Dade. Principals were asked if they could
\end{tabular}

work at any school in the district other than the one they are currently in, what would be their first choice. 
Table 6. Change in School Characteristics among Principals who Transfer

\begin{tabular}{|c|c|c|c|c|c|c|c|c|c|c|c|c|}
\hline \multirow[b]{2}{*}{ Second School Served as Principal } & \multicolumn{2}{|c|}{$\begin{array}{l}\text { Mean Math } \\
\text { Score } \\
\end{array}$} & \multicolumn{2}{|c|}{$\begin{array}{c}\text { Percent Low } \\
\text { Proficiency } \\
\text { in Math } \\
\end{array}$} & \multicolumn{2}{|c|}{$\begin{array}{c}\text { Percent High } \\
\text { Proficiency } \\
\text { in Math } \\
\end{array}$} & \multicolumn{2}{|c|}{$\begin{array}{c}\text { Percent F/R } \\
\text { Lunch }\end{array}$} & \multicolumn{2}{|c|}{$\begin{array}{c}\text { Percent } \\
\text { Black }\end{array}$} & \multicolumn{2}{|c|}{$\begin{array}{c}\text { Percent } \\
\text { Chronically } \\
\text { Absent }\end{array}$} \\
\hline & $\begin{array}{c}17.944 \\
(2.449)\end{array}$ & $* * *$ & $\begin{array}{r}-0.093 \\
(0.014)\end{array}$ & $* * *$ & $\begin{array}{c}0.037 \\
(0.006)\end{array}$ & $* * *$ & $\begin{array}{r}-0.081 \\
(0.025)\end{array}$ & ** & $\begin{array}{c}-0.091 \\
(0.031)\end{array}$ & $* *$ & $\begin{array}{c}-0.027 \\
(0.012)\end{array}$ & $*$ \\
\hline Third School Served as Principal & $\begin{array}{l}19.768 \\
(4.650)\end{array}$ & $* * *$ & $\begin{array}{r}-0.093 \\
(0.026)\end{array}$ & $* * *$ & $\begin{array}{r}0.036 \\
(0.012)\end{array}$ & $* *$ & $\begin{array}{r}-0.088 \\
(0.046)\end{array}$ & + & $\begin{array}{c}-0.093 \\
(0.058)\end{array}$ & & $\begin{array}{c}-0.057 \\
(0.022)\end{array}$ & $* *$ \\
\hline Fourth or Fifth School Served as Principi & $\begin{array}{r}24.930 \\
(9.880)\end{array}$ & $*$ & $\begin{array}{r}-0.156 \\
(0.056)\end{array}$ & ** & $\begin{array}{r}0.035 \\
(0.026)\end{array}$ & & $\begin{array}{r}-0.005 \\
(0.100)\end{array}$ & & $\begin{array}{r}-0.081 \\
(0.126)\end{array}$ & & $\begin{array}{r}-0.040 \\
(0.050)\end{array}$ & \\
\hline Constant & $\begin{array}{c}304.685 \\
(0.996)\end{array}$ & $* * *$ & $\begin{array}{r}0.250 \\
(0.006)\end{array}$ & $* * *$ & $\begin{array}{r}0.060 \\
(0.003)\end{array}$ & $* * *$ & $\begin{array}{r}0.727 \\
(0.010)\end{array}$ & $* * *$ & $\begin{array}{r}0.400 \\
(0.013)\end{array}$ & $* * *$ & $\begin{array}{r}0.107 \\
(0.005)\end{array}$ & $* * *$ \\
\hline Principal Fixed Effect & $\mathrm{X}$ & & $\mathrm{X}$ & & $\mathrm{X}$ & & $\mathrm{X}$ & & $\mathrm{X}$ & & $\mathrm{X}$ & \\
\hline N (Principals) & 516 & & 518 & & 518 & & 522 & & 522 & & 522 & \\
\hline $\mathrm{N}$ (Observations) & 690 & & 696 & & 696 & & 704 & & 704 & & 704 & \\
\hline
\end{tabular}

Notes: $+\mathrm{p}<.10^{*} \mathrm{p}<.05,{ }^{* *} \mathrm{p}<.01,{ }^{* * *} \mathrm{p}<.001$ The first school at which the principal served is the omitted category. 
Table 7. Logistic Regression of Teacher Turnover by Principal Experience (Odds Ratios/t-Statistics)

\begin{tabular}{|c|c|c|c|c|c|}
\hline & $\mathbf{1}$ & & 2 & 3 & \\
\hline \multicolumn{6}{|l|}{ 1. New Principal at School } \\
\hline New Principal & $\begin{array}{r}1.168 \\
(4.464)\end{array}$ & $* * *$ & ${ }_{(3.112)^{* * *}}$ & $\begin{array}{r}1.087 \\
(2.352)\end{array}$ & * \\
\hline \multicolumn{6}{|c|}{ 2. New Principal at School with Control for Prior Experience } \\
\hline New Principal & $\begin{array}{c}1.114 \\
(2.801)\end{array}$ & $* *$ & $\begin{array}{l}1.086 * \\
(2.439)\end{array}$ & $\begin{array}{c}1.074 \\
(0.794)\end{array}$ & \\
\hline Prior Years of Principal Experience (in Any School) & $\begin{array}{r}0.983 \\
(-3.370)\end{array}$ & $* * *$ & $\begin{array}{c}0.991 * \\
(-1.976)\end{array}$ & $\begin{array}{r}0.995 \\
(-0.168)\end{array}$ & \\
\hline \multicolumn{6}{|l|}{ 3. First-Time New Principal at School } \\
\hline First Time New Principal This Year & $\begin{array}{c}1.141 \\
(2.989)\end{array}$ & $* *$ & $\begin{array}{l}1.086 * \\
(2.172)\end{array}$ & $\begin{array}{r}1.075 \\
(1.072)\end{array}$ & \\
\hline $\begin{array}{l}\text { New Principal to School, but with Prior Experience } \\
\text { at another School in District }\end{array}$ & $\begin{array}{r}1.207 \\
(3.743)\end{array}$ & $* * *$ & $\left.{ }^{1.149}\right)^{* *}$ & $\begin{array}{c}1.102 \\
(1.549)\end{array}$ & \\
\hline \multicolumn{6}{|l|}{ 4. Temporary/Interim Principal } \\
\hline Temporary/Interim Principal & $\begin{array}{r}1.101 \\
(2.225)\end{array}$ & * & $\begin{array}{r}1.036 \\
(0.915)\end{array}$ & $\begin{array}{r}1.016 \\
(0.086)\end{array}$ & \\
\hline \multicolumn{6}{|l|}{ 5. Principal Experience } \\
\hline Years at Current School & $\begin{array}{r}0.950 \\
(-2.698)\end{array}$ & $* *$ & $\begin{array}{r}0.972 \\
(-1.584)\end{array}$ & $\begin{array}{r}0.960 \\
(-0.336)\end{array}$ & \\
\hline Time-Varying Teacher Controls & --- & & $\mathrm{X}$ & $\mathrm{X}$ & \\
\hline Time-Varying School Controls & --- & & $\mathrm{X}$ & $\mathrm{X}$ & \\
\hline School Fixed Effect & --- & & --- & $\mathrm{X}$ & \\
\hline Year Fixed Effect & --- & & $\mathrm{X}$ & $\mathrm{X}$ & \\
\hline Clustered SE (School by Year) & $\mathrm{X}$ & & $\mathrm{X}$ & $\mathrm{X}$ & \\
\hline
\end{tabular}

Notes: ${ }^{+} \mathrm{p}<.10^{*}, \mathrm{p}<.05,{ }^{* *} \mathrm{p}<.01,{ }^{* * *} \mathrm{p}<.001$ The outcome is whether the teacher left their school at the end of the year. The models are restricted to teachers under the age of 62 (to omit those who leave due to retirement). Each numbered panel represents a different model. 
Table 8. Regression of Standardized Math Achievement Test Scores on Principal Experience

\begin{tabular}{|c|c|c|c|c|c|c|}
\hline & 1 & & 2 & & 3 & \\
\hline \multicolumn{7}{|l|}{ 1. New Principal at School } \\
\hline New Principal This Year & $\begin{array}{c}-0.005 \\
(0.002)\end{array}$ & $* *$ & $\begin{array}{c}-0.004 \\
(0.002)\end{array}$ & $*$ & $\begin{array}{r}-0.005 \\
(0.002)\end{array}$ & $* *$ \\
\hline Proportion of New Teachers at School & $\begin{array}{c}0.000 \\
(0.006)\end{array}$ & & $\begin{array}{l}-0.019 \\
(0.011)\end{array}$ & + & $\begin{array}{r}-0.080 \\
(0.015)\end{array}$ & $* * *$ \\
\hline \multicolumn{7}{|c|}{ 2. New Principal, Control for Year before New Principal } \\
\hline Year Before New Principal & $\begin{array}{c}-0.002 \\
(0.002)\end{array}$ & & $\begin{array}{c}-0.004 \\
(0.002)\end{array}$ & $*$ & $\begin{array}{r}-0.001 \\
(0.002)\end{array}$ & \\
\hline New Principal This Year & $\begin{array}{l}-0.005 \\
(0.002)\end{array}$ & $* *$ & $\begin{array}{c}-0.005 \\
(0.002)\end{array}$ & $* *$ & $\begin{array}{r}-0.006 \\
(0.002)\end{array}$ & $* * *$ \\
\hline Proportion of New Teachers at School & $\begin{array}{c}0.002 \\
(0.006)\end{array}$ & & $\begin{array}{c}-0.023 \\
(0.011)\end{array}$ & * & $\begin{array}{r}-0.082 \\
(0.016)\end{array}$ & $* * *$ \\
\hline \multicolumn{7}{|l|}{ 3. First-Time New Principal at School } \\
\hline First Time New Principal This Year & $\begin{array}{c}-0.012 \\
(0.002)\end{array}$ & $* * *$ & $\begin{array}{c}-0.011 \\
(0.002)\end{array}$ & $* * *$ & $\begin{array}{r}-0.010 \\
(0.002)\end{array}$ & $* * *$ \\
\hline $\begin{array}{l}\text { New Principal to School, but with Prior Experience } \\
\text { at another School in District }\end{array}$ & $\begin{array}{c}0.002 \\
(0.002)\end{array}$ & & $\begin{array}{c}0.003 \\
(0.002)\end{array}$ & & $\begin{array}{r}-0.000 \\
(0.002)\end{array}$ & \\
\hline Proportion of New Teachers at School & $\begin{array}{l}-0.005 \\
(0.006)\end{array}$ & & $\begin{array}{l}-0.024 \\
(0.011)\end{array}$ & * & $\begin{array}{r}-0.088 \\
(0.015)\end{array}$ & $* * *$ \\
\hline \multicolumn{7}{|l|}{ 4. Temporary/Interim Principal } \\
\hline Temporary/Interim Principal & $\begin{array}{l}-0.004 \\
(0.002)\end{array}$ & + & $\begin{array}{l}-0.004 \\
(0.002)\end{array}$ & $*$ & $\begin{array}{r}-0.011 \\
(0.002)\end{array}$ & $* * *$ \\
\hline Proportion of New Teachers at School & $\begin{array}{l}-0.007 \\
(0.005)\end{array}$ & & $\begin{array}{l}-0.018 \\
(0.008)\end{array}$ & $*$ & $\begin{array}{r}-0.064 \\
(0.011)\end{array}$ & $* * *$ \\
\hline \multicolumn{7}{|l|}{ 5. Principal Experience (Continuous) } \\
\hline Years at Current School & $\begin{array}{c}0.001 \\
(0.001)\end{array}$ & & $\begin{array}{c}0.004 \\
(0.001)\end{array}$ & $* *$ & $\begin{array}{r}0.003 \\
(0.001)\end{array}$ & $* *$ \\
\hline Proportion of New Teachers at School & $\begin{array}{c}0.003 \\
(0.006)\end{array}$ & & $\begin{array}{l}-0.018 \\
(0.011)\end{array}$ & + & $\begin{array}{r}-0.081 \\
(0.015)\end{array}$ & $* * *$ \\
\hline \multicolumn{7}{|l|}{ 6. New Principal with Interactions } \\
\hline New Principal This Year & $\begin{array}{c}-0.002 \\
(0.003)\end{array}$ & & $\begin{array}{c}-0.013 \\
(0.003)\end{array}$ & $* * *$ & & \\
\hline Prior Years of Principal Experience (Any School) & $\begin{array}{c}0.002 \\
(0.000)\end{array}$ & $* * *$ & $\begin{array}{c}0.000 \\
(0.001)\end{array}$ & & & \\
\hline New Principal*Prior Years Principal Experience & $\begin{array}{c}0.001 \\
(0.001)\end{array}$ & & $\begin{array}{c}0.004 \\
(0.001)\end{array}$ & $* * *$ & & \\
\hline Control for Lag of Outcome & $\mathrm{X}$ & & $\mathrm{X}$ & & $\mathrm{X}$ & \\
\hline Time-Varying Student Controls & $\mathrm{X}$ & & $\mathrm{X}$ & & $\mathrm{X}$ & \\
\hline Time-Varying School Controls & $\mathrm{X}$ & & $\mathrm{X}$ & & $\mathrm{X}$ & \\
\hline Time-Varying Classroom Controls & $\mathrm{X}$ & & $\mathrm{X}$ & & $\mathrm{X}$ & \\
\hline School Fixed Effect & --- & & $\mathrm{X}$ & & $\mathrm{X}$ & \\
\hline Student Fixed Effect & --- & & --- & & $\mathrm{X}$ & \\
\hline Grade Fixed Effect & $\mathrm{X}$ & & $\mathrm{X}$ & & $\mathrm{X}$ & \\
\hline Year Fixed Effect & $\mathrm{X}$ & & $\mathrm{X}$ & & $\mathrm{X}$ & \\
\hline
\end{tabular}

Notes: $+\mathrm{p}<.10,{ }^{*} \mathrm{p}<.05,{ }^{* *} \mathrm{p}<.01,{ }^{* * *} \mathrm{p}<.001$ Test scores are standardized to have a mean of 0 and a standard deviation of 1 within each year and grade. Each numbered panel represents a separate model. Time-varying student-level controls include limited English proficiency, free or reduced priced lunch eligibility, and retention status. Class characteristics include percent black, percent female, percent eligible for free or reduced priced lunches, percent limited English proficicient and average prior achievement. School-level controls include percent minority and percent eligible for free or reduced priced lunches. 
Table 9. Regression of Standardized Reading Achievement Test Scores on Principal Experience

\begin{tabular}{|c|c|c|c|c|c|c|}
\hline & 1 & & 2 & & 3 & \\
\hline \multicolumn{7}{|l|}{ 1. New Principal at School } \\
\hline New Principal This Year & $\begin{array}{c}-0.011 \\
(0.002)\end{array}$ & $* * *$ & $\begin{array}{c}-0.005 \\
(0.002)\end{array}$ & * & $\begin{array}{c}-0.004 \\
(0.002)\end{array}$ & * \\
\hline Proportion of New Teachers at School & $\begin{array}{c}-0.007 \\
(0.006)\end{array}$ & & $\begin{array}{c}-0.022 \\
(0.011)\end{array}$ & + & $\begin{array}{c}-0.022 \\
(0.017)\end{array}$ & \\
\hline \multicolumn{7}{|c|}{ 2. New Principal, Control for Year before New Principal } \\
\hline Year Before New Principal & $\begin{array}{c}-0.010 \\
(0.002)\end{array}$ & $* * *$ & $\begin{array}{c}-0.002 \\
(0.002)\end{array}$ & & $\begin{array}{c}-0.003 \\
(0.002)\end{array}$ & \\
\hline New Principal This Year & $\begin{array}{c}-0.012 \\
(0.002)\end{array}$ & $* * *$ & $\begin{array}{c}-0.005 \\
(0.002)\end{array}$ & * & $\begin{array}{c}-0.005 \\
(0.002)\end{array}$ & * \\
\hline Proportion of New Teachers at School & $\begin{array}{c}-0.007 \\
(0.006)\end{array}$ & & $\begin{array}{c}-0.023 \\
(0.011)\end{array}$ & * & $\begin{array}{c}-0.022 \\
(0.017)\end{array}$ & \\
\hline \multicolumn{7}{|l|}{ 3. First-Time New Principal at School } \\
\hline First Time New Principal This Year & $\begin{array}{c}-0.016 \\
(0.002)\end{array}$ & $* * *$ & $\begin{array}{c}-0.005 \\
(0.003)\end{array}$ & * & $\begin{array}{c}-0.004 \\
(0.002)\end{array}$ & \\
\hline $\begin{array}{l}\text { New Principal to School, but with Prior Experience } \\
\text { at another School in District }\end{array}$ & $\begin{array}{l}-0.007 \\
(0.002)\end{array}$ & ** & $\begin{array}{l}-0.004 \\
(0.003)\end{array}$ & + & $\begin{array}{l}-0.005 \\
(0.002)\end{array}$ & * \\
\hline Proportion of New Teachers at School & $\begin{array}{l}-0.010 \\
(0.006)\end{array}$ & & $\begin{array}{l}-0.022 \\
(0.011)\end{array}$ & * & $\begin{array}{l}-0.021 \\
(0.017)\end{array}$ & \\
\hline \multicolumn{7}{|l|}{ 4. Temporary/Interim Principal } \\
\hline Temporary/Interim Principal & $\begin{array}{l}-0.007 \\
(0.002)\end{array}$ & $* *$ & $\begin{array}{c}0.000 \\
(0.002)\end{array}$ & & $\begin{array}{l}-0.002 \\
(0.002)\end{array}$ & \\
\hline Proportion of New Teachers at School & $\begin{array}{l}-0.019 \\
(0.005)\end{array}$ & $* * *$ & $\begin{array}{l}-0.017 \\
(0.008)\end{array}$ & * & $\begin{array}{l}-0.022 \\
(0.012)\end{array}$ & + \\
\hline \multicolumn{7}{|l|}{ 5. Principal Experience (Continuous) } \\
\hline Years at Current School & $\begin{array}{c}0.006 \\
(0.001)\end{array}$ & $* * *$ & $\begin{array}{c}0.004 \\
(0.001)\end{array}$ & $* * *$ & $\begin{array}{c}0.004 \\
(0.001)\end{array}$ & ** \\
\hline Proportion of New Teachers at School & $\begin{array}{l}-0.001 \\
(0.006)\end{array}$ & & $\begin{array}{l}-0.020 \\
(0.011)\end{array}$ & + & $\begin{array}{l}-0.020 \\
(0.017)\end{array}$ & \\
\hline \multicolumn{7}{|l|}{ 6. New Principal with Interactions } \\
\hline New Principal This Year & $\begin{array}{c}0.002 \\
(0.003)\end{array}$ & & $\begin{array}{c}-0.001 \\
(0.003)\end{array}$ & & & \\
\hline Prior Years of Principal Experience (Any School) & $\begin{array}{c}0.003 \\
(0.000)\end{array}$ & $* * *$ & $\begin{array}{c}0.002 \\
(0.001)\end{array}$ & $* * *$ & & \\
\hline New Principal*Prior Years Principal Experience & $\begin{array}{c}-0.002 \\
(0.001)\end{array}$ & ** & $\begin{array}{c}-0.000 \\
(0.001)\end{array}$ & & & \\
\hline Control for Lag of Outcome & $\mathrm{X}$ & & $\mathrm{X}$ & & $\mathrm{X}$ & \\
\hline Time-Varying Student Controls & $\mathrm{X}$ & & $\mathrm{X}$ & & $\mathrm{X}$ & \\
\hline Time-Varying School Controls & $\mathrm{X}$ & & $\mathrm{X}$ & & $\mathrm{X}$ & \\
\hline Time-Varying Classroom Controls & $\mathrm{X}$ & & $\mathrm{X}$ & & $\mathrm{X}$ & \\
\hline School Fixed Effect & --- & & $\mathrm{X}$ & & $\mathrm{X}$ & \\
\hline Student Fixed Effect & --- & & --- & & $\mathrm{X}$ & \\
\hline Grade Fixed Effect & $\mathrm{X}$ & & $X$ & & $X$ & \\
\hline Year Fixed Effect & $\mathrm{X}$ & & $\mathrm{X}$ & & $\mathrm{X}$ & \\
\hline
\end{tabular}

Notes: $+\mathrm{p}<.10,{ }^{*} \mathrm{p}<.05,{ }^{* *} \mathrm{p}<.01,{ }^{* * *} \mathrm{p}<.001$ Test scores are standardized to have a mean of 0 and a standard deviation of 1 within each year and grade. Each numbered panel represents a separate model. Time-varying student-level controls include limited English proficiency, free or reduced priced lunch eligibility, and retention status. Class characteristics include percent black, percent female, percent eligible for free or reduced priced lunches, percent limited English proficicient and average prior achievement. School-level controls include percent minority and percent eligible for free or reduced priced lunches. 


\begin{tabular}{|c|c|c|c|c|c|c|c|c|c|c|c|c|}
\hline \multirow{3}{*}{ MATHACHIEVEMENT } & \multicolumn{4}{|c|}{$\begin{array}{c}\text { School Characteristic= } \\
\text { Failing School }\end{array}$} & \multicolumn{4}{|c|}{$\begin{array}{c}\text { School Characteristic= } \\
\text { High Poverty School }\end{array}$} & \multicolumn{4}{|c|}{$\begin{array}{c}\text { School Characteristic }= \\
\text { Top Quartile of First Year } \\
\text { Teachers }\end{array}$} \\
\hline & \multirow[t]{2}{*}{$(1)$} & \multicolumn{3}{|c|}{$(2)$} & \multirow[t]{2}{*}{$(3)$} & \multicolumn{3}{|c|}{$(4)$} & \multirow[t]{2}{*}{$(5)$} & \multicolumn{3}{|c|}{$(6)$} \\
\hline \multirow{2}{*}{\multicolumn{13}{|c|}{ 1. New Principal at School }} \\
\hline & & & & & & & & & & & & \\
\hline New Principal & $\begin{array}{r}-0.001 \\
(0.002)\end{array}$ & & $\begin{array}{r}-0.003 \\
(0.002)\end{array}$ & & $\begin{array}{r}-0.003 \\
(0.002)\end{array}$ & & $\begin{array}{r}-0.000 \\
(0.002)\end{array}$ & & $\begin{array}{l}-0.002 \\
(0.002)\end{array}$ & & $\begin{array}{l}-0.003 \\
(0.002)\end{array}$ & + \\
\hline New Principal*School Characteristics & $\begin{array}{r}-0.047 \\
(0.016)\end{array}$ & $* *$ & $\begin{array}{r}-0.038 \\
(0.016)\end{array}$ & * & $\begin{array}{r}-0.006 \\
(0.006)\end{array}$ & & $\begin{array}{r}-0.020 \\
(0.005)\end{array}$ & $* * *$ & $\begin{array}{l}-0.017 \\
(0.005)\end{array}$ & $* * *$ & $\begin{array}{l}-0.015 \\
(0.004)\end{array}$ & $* * *$ \\
\hline \multicolumn{13}{|l|}{ 2. Principal Experience at a School } \\
\hline Principal Experience & $\begin{array}{r}0.003 \\
(0.002)\end{array}$ & * & $\begin{array}{r}0.002 \\
(0.002)\end{array}$ & & $\begin{array}{r}0.003 \\
(0.001)\end{array}$ & * & $\begin{array}{r}0.002 \\
(0.001)\end{array}$ & & $\begin{array}{c}0.002 \\
(0.001)\end{array}$ & & $\begin{array}{c}0.001 \\
(0.001)\end{array}$ & \\
\hline Principal Experience*School Characteristic & $\begin{array}{r}-0.008 \\
(0.067)\end{array}$ & & $\begin{array}{r}0.120 \\
(0.070)\end{array}$ & + & $\begin{array}{r}0.007 \\
(0.004)\end{array}$ & + & $\begin{array}{c}0.013 \\
(0.004)\end{array}$ & $* *$ & $\begin{array}{c}0.011 \\
(0.003)\end{array}$ & $* * *$ & $\begin{array}{c}0.010 \\
(0.003)\end{array}$ & $* * *$ \\
\hline \multicolumn{13}{|l|}{ READING ACHIEVEMENT } \\
\hline \multicolumn{13}{|l|}{ 1. New Principal at School } \\
\hline New Principal & $\begin{array}{r}-0.005 \\
(0.002)\end{array}$ & * & $\begin{array}{r}-0.004 \\
(0.002)\end{array}$ & $*$ & $\begin{array}{r}0.000 \\
(0.002)\end{array}$ & & $\begin{array}{r}0.000 \\
(0.002)\end{array}$ & & $\begin{array}{l}-0.004 \\
(0.002)\end{array}$ & + & $\begin{array}{l}-0.003 \\
(0.002)\end{array}$ & \\
\hline New Principal*School Characteristics & $\begin{array}{r}-0.020 \\
(0.016)\end{array}$ & & $\begin{array}{r}-0.062 \\
(0.015)\end{array}$ & $* * *$ & $\begin{array}{r}-0.016 \\
(0.005)\end{array}$ & $* *$ & $\begin{array}{r}-0.032 \\
(0.005)\end{array}$ & $* * *$ & $\begin{array}{l}-0.005 \\
(0.005)\end{array}$ & & $\begin{array}{l}-0.006 \\
(0.005)\end{array}$ & \\
\hline \multicolumn{13}{|l|}{ 2. Principal Experience at a School } \\
\hline Principal Experience & $\begin{array}{r}0.005 \\
(0.001)\end{array}$ & $* * *$ & $\begin{array}{r}0.003 \\
(0.001)\end{array}$ & + & $\begin{array}{r}0.002 \\
(0.001)\end{array}$ & + & $\begin{array}{r}0.001 \\
(0.001)\end{array}$ & & $\begin{array}{c}0.004 \\
(0.001)\end{array}$ & $* *$ & $\begin{array}{c}0.004 \\
(0.001)\end{array}$ & $*$ \\
\hline Principal Experience*School Characteristic & $\begin{array}{r}-0.261 \\
(0.063)\end{array}$ & $* * *$ & $\begin{array}{r}-0.018 \\
(0.065)\end{array}$ & & $\begin{array}{r}0.009 \\
(0.004)\end{array}$ & ** & $\begin{array}{r}0.018 \\
(0.004)\end{array}$ & $* * *$ & $\begin{array}{c}0.002 \\
(0.003)\end{array}$ & & $\begin{array}{l}-0.001 \\
(0.003)\end{array}$ & \\
\hline Control for Percent New Teachers to School & $\mathrm{X}$ & & $\mathrm{X}$ & & $\mathrm{X}$ & & $\mathrm{X}$ & & $\mathrm{X}$ & & $\mathrm{X}$ & \\
\hline Control for Lag of Outcome & $\mathrm{X}$ & & $\mathrm{X}$ & & $\mathrm{X}$ & & $\mathrm{X}$ & & $\mathrm{X}$ & & $\mathrm{X}$ & \\
\hline Time-Varying Student, School, Class Controls & $\mathrm{X}$ & & $\mathrm{X}$ & & $\mathrm{X}$ & & $\mathrm{X}$ & & $\mathrm{X}$ & & $\mathrm{X}$ & \\
\hline School Fixed Effect & $\mathrm{X}$ & & $\mathrm{X}$ & & $\mathrm{X}$ & & $\mathrm{X}$ & & $\mathrm{X}$ & & $\mathrm{X}$ & \\
\hline Student Fixed Effect & --- & & $\mathrm{X}$ & & --- & & $\mathrm{X}$ & & --- & & $\mathrm{X}$ & \\
\hline Grade Fixed Effect & $\mathrm{X}$ & & $\mathrm{X}$ & & $\mathrm{X}$ & & $\mathrm{X}$ & & $\mathrm{X}$ & & $\mathrm{X}$ & \\
\hline Year Fixed Effect & $\mathrm{X}$ & & $\mathrm{X}$ & & $X$ & & $X$ & & $X$ & & $X$ & \\
\hline
\end{tabular}

Notes: $+\mathrm{p}<.10,{ }^{*} \mathrm{p}<.05,{ }^{* *} \mathrm{p}<.01,{ }^{* * *} \mathrm{p}<.001$ Test scores are standardized to have a mean of 0 and a standard deviation of 1 within each grade and year. Failing schools are those that received an accountability grade of $F$ in the prior year. High poverty schools are those in the top quartile of students receiving free or reduced priced lunches. Poverty status, accountability grades, and the first year teacher measure vary within schools across years so all models also include a main effect for these measures that are not shown in the table. 
Table 11. Characteristics of Principals by School Type

\begin{tabular}{|c|c|c|c|c|c|c|c|}
\hline & \multicolumn{3}{|c|}{ New Principals to a School } & \multicolumn{4}{|c|}{ All Principals at a School } \\
\hline & $\begin{array}{l}\text { \% with Prior } \\
\text { Prin Exp }\end{array}$ & $\begin{array}{c}\text { Yrs Prin } \\
\text { Experience }\end{array}$ & $\begin{array}{l}\text { Master's } \\
\text { Degree }\end{array}$ & $\begin{array}{c}\text { Yrs Prin } \\
\text { Experience }\end{array}$ & $\begin{array}{l}\text { Yrs Prin } \\
\text { at School }\end{array}$ & $\begin{array}{c}\text { Master's } \\
\text { Degree }\end{array}$ & $\begin{array}{c}\text { First Yr } \\
\text { Principal }\end{array}$ \\
\hline \multicolumn{8}{|l|}{ Free Lunch Quartiles } \\
\hline Quartile 1 (Low Poverty) & 0.65 & 3.94 & 0.65 & 4.75 & 3.07 & 0.70 & 0.11 \\
\hline Quartile 4 (High Poverty) & 0.30 & 2.21 & 0.56 & 3.43 & 2.48 & 0.62 & 0.20 \\
\hline \multicolumn{8}{|l|}{ Math Low Ach Quartiles } \\
\hline Quartile 1 (Few Low Ach) & 0.66 & 3.34 & 0.55 & 5.50 & 3.77 & 0.72 & 0.07 \\
\hline Quartile 4 (Many Low Ach) & 0.38 & 2.40 & 0.61 & 2.99 & 2.37 & 0.65 & 0.21 \\
\hline \multicolumn{8}{|l|}{ Reading Low Ach Quartiles } \\
\hline Quartile 1 (Few Low Ach) & 0.61 & 3.63 & 0.61 & 5.47 & 3.63 & 0.73 & 0.09 \\
\hline Quartile 4 (Many Low Ach) & 0.47 & 2.79 & 0.64 & 2.84 & 2.22 & 0.64 & 0.23 \\
\hline \multicolumn{8}{|c|}{ School Accountability Grades } \\
\hline A & 0.46 & 2.92 & 0.57 & 5.08 & 3.43 & 0.69 & 0.13 \\
\hline $\mathrm{F}$ & 0.50 & 3.10 & 0.30 & 2.47 & 1.97 & 0.67 & 0.26 \\
\hline
\end{tabular}

